\title{
Influence of Green Manure and Potassium Nutrition on Soil Potassium Fractions and Yield of Rice Crop
}

\author{
D.V. Sujatha*, P. Kavitha and M.V.S. Naidu \\ Department of Soil Science and Agricultural Chemistry, Agricultural College, Acharya N.G \\ Ranga Agricultural University, Mahanandi- 518502, A.P., India \\ *Corresponding author
}

\begin{tabular}{|c|}
\hline Keywords \\
\hline $\begin{array}{l}\text { Water soluble K, } \\
\text { Exchangeable K, } \\
\text { Fixed K, Non- } \\
\text { exchangeable K and } \\
\text { dhaincha. }\end{array}$ \\
\hline Article Info \\
\hline $\begin{array}{l}\text { Accepted: } \\
\text { 04 September } 2017 \\
\text { Available Online: } \\
10 \text { November } 2017\end{array}$ \\
\hline
\end{tabular}

A B S T R A C T

A field experiment was conducted with rice during kharif 2015 at Agricultural college farm, Mahanandi to study the influence of different levels of potassium either alone or in combination with green manure on yield and soil $\mathrm{K}$ fractions (water soluble, exchangeable, fixed and non-exchangeable forms) at different stages of rice crop. All the forms of $\mathrm{K}$ increased with increasing levels of potassium up to $120 \mathrm{~kg} \mathrm{~K}_{2} \mathrm{O} \mathrm{ha}{ }^{-1}$ at all the stages of crop growth.Green manure either alone or in combination with $\mathrm{K}$ fertilizer recorded higher values of exchangeable $\mathrm{K}$ and yield as compared with fertilizer treatments alone. The results clearly indicated that increase in fixed $\mathrm{K}$ with increasing fertilizer doses from 0 to $120 \mathrm{~kg} \mathrm{~K}_{2} \mathrm{O} \mathrm{ha}{ }^{-1}$ at all the stages of crop growth. The highest fixed $\mathrm{K}$ and nonexchangeable $\mathrm{K}$ was observed at $120 \mathrm{~kg} \mathrm{~K}_{2} \mathrm{O} \mathrm{ha}{ }^{-1}\left(\mathrm{~T}_{4}\right)$. Whereas the highest yield, water soluble and exchangeable form were obtained with the treatment $\left(\mathrm{T}_{8}\right) \mathrm{GM}+120 \mathrm{~kg} \mathrm{~K}_{2} \mathrm{O}$ $\mathrm{ha}^{-1}$ which was on par with $\left(\mathrm{T}_{7}\right) \mathrm{GM}+80 \mathrm{~kg} \mathrm{~K}_{2} \mathrm{O} \mathrm{ha}^{-1}$ and $\left(\mathrm{T}_{6}\right) \mathrm{GM}+40 \mathrm{~kg} \mathrm{~K}_{2} \mathrm{O} \mathrm{ha}^{-1}$. Hence, the incorporation of green manure (dhaincha) at flowering stage before transplantation along with $40 \mathrm{~kg} \mathrm{~K}_{2} \mathrm{O} \mathrm{ha}^{-1}$ may be recommended for rice crop. However, the results will have to be confirmed by conducting extensive field trails in farmer's fields on long term basis.

\section{Introduction}

Potassium plays a very instrumental role in plant nutrition and physiology and it has been found to activate more than sixty enzymes. In soils, potassium exists in various forms such as water soluble, exchangeable, nonexchangeable, fixed $\mathrm{K}$, lattice $\mathrm{K}$ and total $\mathrm{K}$. The above forms of $\mathrm{K}$ are in equilibrium and related to each other (Das et al., 2000). Dynamic equilibrium reactions occurring between different forms of $\mathrm{K}$ have a profound effect on the $\mathrm{K}$ nutrition and the direction of rate of these reactions determines the fate of applied $\mathrm{K}$ and release of non- exchangeable K (Singh et al., 2004). Rice is an important food crop in the world. It is the staple food in South-East Asia and at present more than half of the world population depends on this crop. It is also one of the most important cereals in India and occupies second position in cultivation after wheat. Rice is one of the major field crops in Kurnool district, the crop is cultivated in an area of 91,568 ha (Department of Agriculture, 2014). The higher grain yield of rice was observed with application of $50 \%$ of RDP either alone or in combination with green manure in Vertisol of 
high available phosphorus in KC canal ayacut of Nandyl (Jyothi, 2013).The soils of Agricultural college farm, Mahanandi were high in available $\mathrm{K}$ and $\mathrm{K}$ supplying power of rice growing soils of canal ayacut in Kurnool district is low as indicated by $\mathrm{PBC}^{\mathrm{K}}$. Hence judicious application of potassic fertilizer is required for better crop production were reported by Prasad (2014) and Swamanna (2015). Incorporation of dhaincha at flowering stage before transplanting of rice was followed by most of the farmers in major rice growing areas of Kurnool district. Though much work has been reported on green manure in combination with $\mathrm{N}$ and $\mathrm{P}$ in rice crop but no investigation have been carried out in green manure along with $\mathrm{K}$ fertilizer in rice crop. Hence, present investigation will be carried out to know the yield and different forms of $\mathrm{K}$ as influenced by green manure and potassium at different stages of crop growth in rice.

\section{Materials and Methods}

A field experiment was conducted at Agricultural College Farm, Mahanandi in Kurnool district of Andhra Pradesh during Kharif 2015. The soils of experimental field was sandy loam with soil $\mathrm{pH} 7.97$, EC 0.33 $\mathrm{dSm}^{-1}$, organic carbon $0.55 \%$, low in available $\mathrm{N}\left(239 \mathrm{~kg} \mathrm{ha}^{-1}\right)$, high in $\mathrm{P}_{2} \mathrm{O}_{5}\left(82 \mathrm{~kg} \mathrm{ha}^{-1}\right)$ and $\mathrm{K}_{2} \mathrm{O} \quad\left(1075 \mathrm{~kg} \mathrm{ha}^{-1}\right)$ respectively. Eight treatments viz., $0,40,80$ and $120 \mathrm{~kg} \mathrm{~K}_{2} \mathrm{O} \mathrm{ha}^{-1}$ alone and in combinations with green manure were employed. The treatment details are given in table 1, which were laid out in randomized block design and replicated thrice. A common recommended dose of nitrogen (240 kg N ha $\left.{ }^{-1}\right)$ and phosphorus (80 $\mathrm{kg} \mathrm{P}_{2} \mathrm{O}_{5} \mathrm{ha}^{-1}$ ) were applied to all the treatments. Nitrogen in the form of urea was applied in three equal splits as basal, at tillering and at panicle initiation stages. Phosphorus in the form of single super phosphate was applied basally. Potassium in the form of muriate of potash was applied in two equal splits as basal and at panicle initiation stage as per the treatments. Green manure (dhaincha) was grown in the treatments $\mathrm{T}_{5}, \mathrm{~T}_{6}, \mathrm{~T}_{7}$ and $\mathrm{T}_{8}$ ploughed in situ at flowering before transplantation. The content of $\mathrm{N}, \mathrm{P}$ and $\mathrm{K}$ in green manure was 3.5, 0.3 and 1 percent respectively. The grains from each plot were cleaned sundried and constant weight was recorded and expressed in $\mathrm{kg} \mathrm{ha}^{-1}$. The straw from each net plot was allowed to dry in the field until a constant weight was obtained and the final weight was recorded and expressed in $\mathrm{kg} \mathrm{ha}{ }^{-1}$. After transplantation representative soil samples were collected from each treatment plot at tillering, panicle initiation and harvest stages, was dried and processed for analysis. Water soluble potassium was determined in 1:5 soil: water extract by equilibrating for 5 minutes (Kanwar and Grewal, 1966). The available potassium was determined by Neutral normal ammonium acetate method with 1:5 soil: water extract, shaking for 5 minutes as described by Jackson (1973). The exchangeable potassium was obtained as a difference of the available and water soluble potassium. The fixed form of potassium was estimated using $1 N \mathrm{HNO}_{3}$ (1:10 soil: acid ratio) boiling for 10 minutes (Wood and De Turk, 1941).The non-exchangeable potassium was obtained by deducting the available potassium from fixed potassium.

\section{Results and Discussion}

\section{Water soluble $\mathrm{K}$}

The data pertaining to water soluble $\mathrm{K}$ at tillering, panicle initiation and harvest stages indicated that water soluble $\mathrm{K}$ significantly varied due to the different treatments at all the stages of crop growth (Table 1; Fig. 1).

At tillering stage green manure either alone or in combination with $\mathrm{K}$ fertilizer recorded 
higher values of water soluble $\mathrm{K}$ as compared with fertilizer treatments alone. But at panicle initiation and harvest stages, $\mathrm{K}$ fertilizer treatments and green manure treatments also equally effective in increasing water soluble $\mathrm{K}$. The water soluble $\mathrm{K}$ increased in $\mathrm{K}$ fertilizer treatments from tillering to harvesting stage while decreased in green manure treatments.

This might be due to the green manure hold the $\mathrm{K}$ in exchangeable sites there by decreased the water soluble form. Among all treatments $\mathrm{T}_{8}, \mathrm{~T}_{7}$ and $\mathrm{T}_{4}$ almost equally effective in increasing water soluble $\mathrm{K}$ when compared to other treatments. The lowest water soluble $\mathrm{K}$ was observed in control $\left(\mathrm{T}_{1}\right)$ but it was on par with $\mathrm{T}_{2}\left(40 \mathrm{~kg} \mathrm{~K}_{2} \mathrm{O} \mathrm{ha}^{-1}\right)$ at all the stages of crop growth.

\section{Exchangeable K}

The exchangeable $\mathrm{K}$ significantly increased with increasing levels of $\mathrm{K}$ fertilizer application and also with green manure incorporation (Table 1; Fig. 2).

The increase in exchangeable $\mathrm{K}$ at $120 \mathrm{~kg} \mathrm{ha}^{-1}$ over no potassium application was $2.8,7.8$ and 8.4 percent at panicle initiation and harvesting stage, respectively. Green manuring in situ alone also significantly increased the exchangeable $\mathrm{K}$ when compared to $\mathrm{T}_{1}$ (Control) and $\mathrm{T}_{2}\left(40 \mathrm{~kg} \mathrm{~K}_{2} \mathrm{O} \mathrm{ha}^{-1}\right)$.

Compared to green manuring and $\mathrm{K}$ fertilizer alone, their combinations recorded higher values of exchangeable $K$ at all the stages of crop growth. Among all treatments higher exchangeable $\mathrm{K}$ obtained with $\mathrm{T}_{8}$ (G.M+ 120 $\mathrm{kg} \mathrm{K}_{2} \mathrm{O} \mathrm{ha}^{-1}$ ) but it was at par with $\mathrm{T} 7$ (G.M + $\left.80 \mathrm{~kg} \mathrm{~K}_{2} \mathrm{O} \mathrm{ha}{ }^{-1}\right)$ and $\mathrm{T}_{6}\left(\mathrm{G} . \mathrm{M}+40 \mathrm{~kg} \mathrm{~K}_{2} \mathrm{O}\right.$ $\mathrm{ha}^{-1}$ ) at all the stages of crop growth.

The higher exchangeable $\mathrm{K}$ obtained with green manuring along with higher dose of $\mathrm{K}$ fertilizer was due to the extensive root system of green manure crops may improved the physical condition of soil and liberated $\mathrm{CO}_{2}$ and organic acids which helped in dissolving native potassium in soil and thus increasing the availability of K (Swarup, 1991; Dhudhan et al., 2004; Singh et al., 2009).

\section{Fixed K}

Unlike exchangeable $\mathrm{K}$, the fixed $\mathrm{K}$ increased from tillering to harvest stage (Table 1; Fig 3). At tillering stage, the highest fixed $\mathrm{K}$ was observed in control except $\mathrm{T}_{8}$ (G.M+120 kg $\mathrm{K}_{2} \mathrm{O} \mathrm{ha}^{-1}$ ) due to lower uptake of $\mathrm{K}$ in control.

However later stages i.e., panicle initiation and harvest stage, the lowest fixed $\mathrm{K}$ observed in control due to the absence of $\mathrm{K}$ fertilization and significant depletion of fixed $\mathrm{K}$ when compared to other treatments.

Syers et al., (2011) also reported that, in the absence of adequate $\mathrm{K}$ fertilization significant depletion of $\mathrm{K}$ reserves in soil take place leading to yield loss and higher economic risk to farmers.

The highest fixed $\mathrm{K}$ observed with $\mathrm{T}_{8}(\mathrm{G} . \mathrm{M}+$ $120 \mathrm{~kg} \mathrm{~K}_{2} \mathrm{O} \mathrm{ha}^{-1}$ ) at tillering stage was due to the excess $\mathrm{K}$ fertilizer application and conversion of water soluble and exchangeable form to fixed form.

Later stages i.e., panicle initiation and harvest stage the highest fixed $\mathrm{K}$ was observed at 120 $\mathrm{kg} \mathrm{K}_{2} \mathrm{O} \mathrm{ha}^{-1}\left(\mathrm{~T}_{4}\right)$. The results clearly indicated that increase in fixed $\mathrm{K}$ with increasing fertilizer doses from 0 to $120 \mathrm{~kg} \mathrm{~K}_{2} \mathrm{O} \mathrm{ha}^{-1}$ at all the stages of crop growth.

These findings indicate that addition of higher doses of fertilizers increases the fixation capacity of soil. Rao et al., (2000) also reported that fixation of added $\mathrm{K}$ with the rate of added $\mathrm{K}$ irrespective of soil mineralogy. 
Fig.1 Water soluble $\mathrm{K}$ as influenced by different levels of potassium and green manure at different stages of crop growth

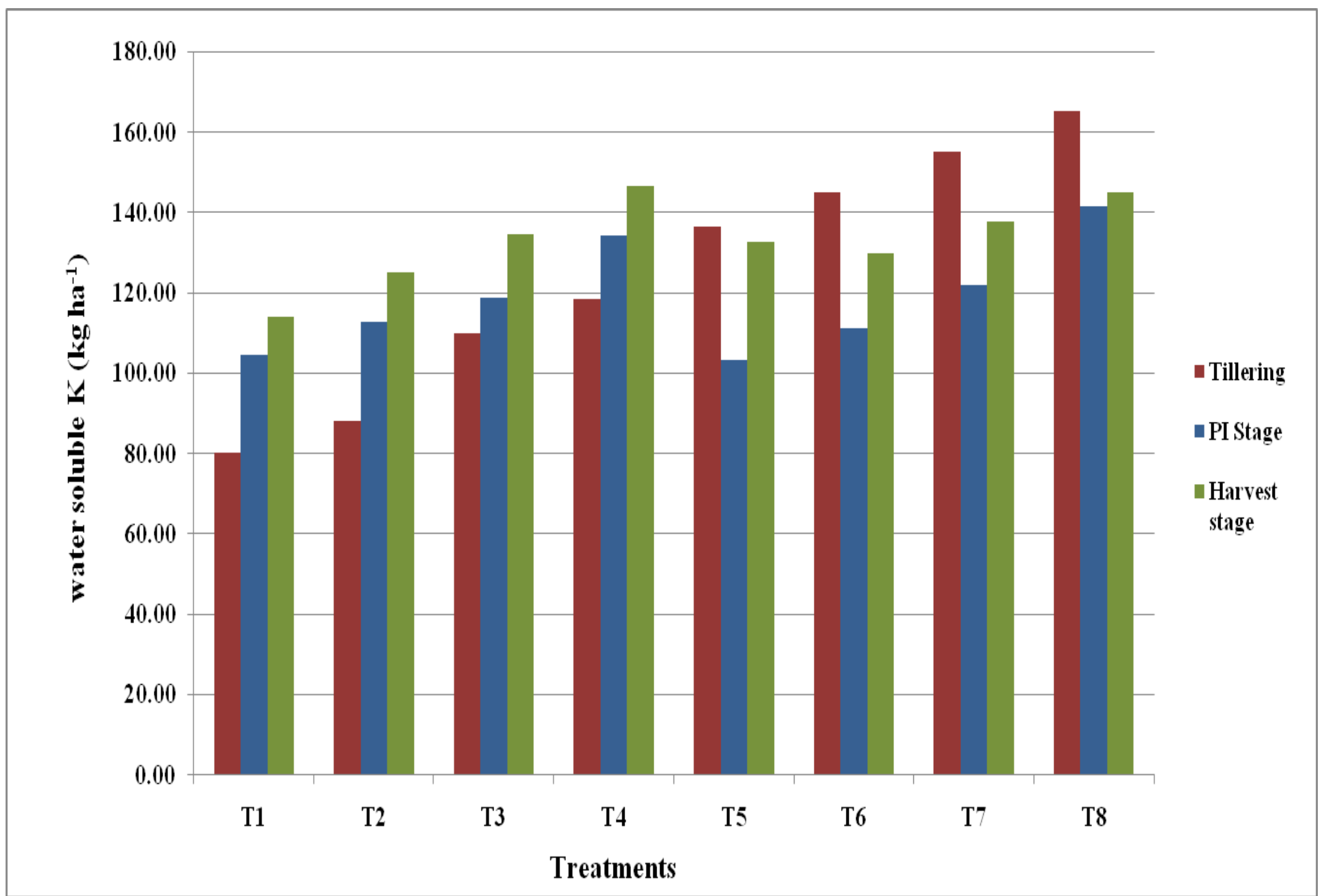


Fig.2 Exchangeable K as influenced by different levels of potassium and green manure at different stages of crop growth

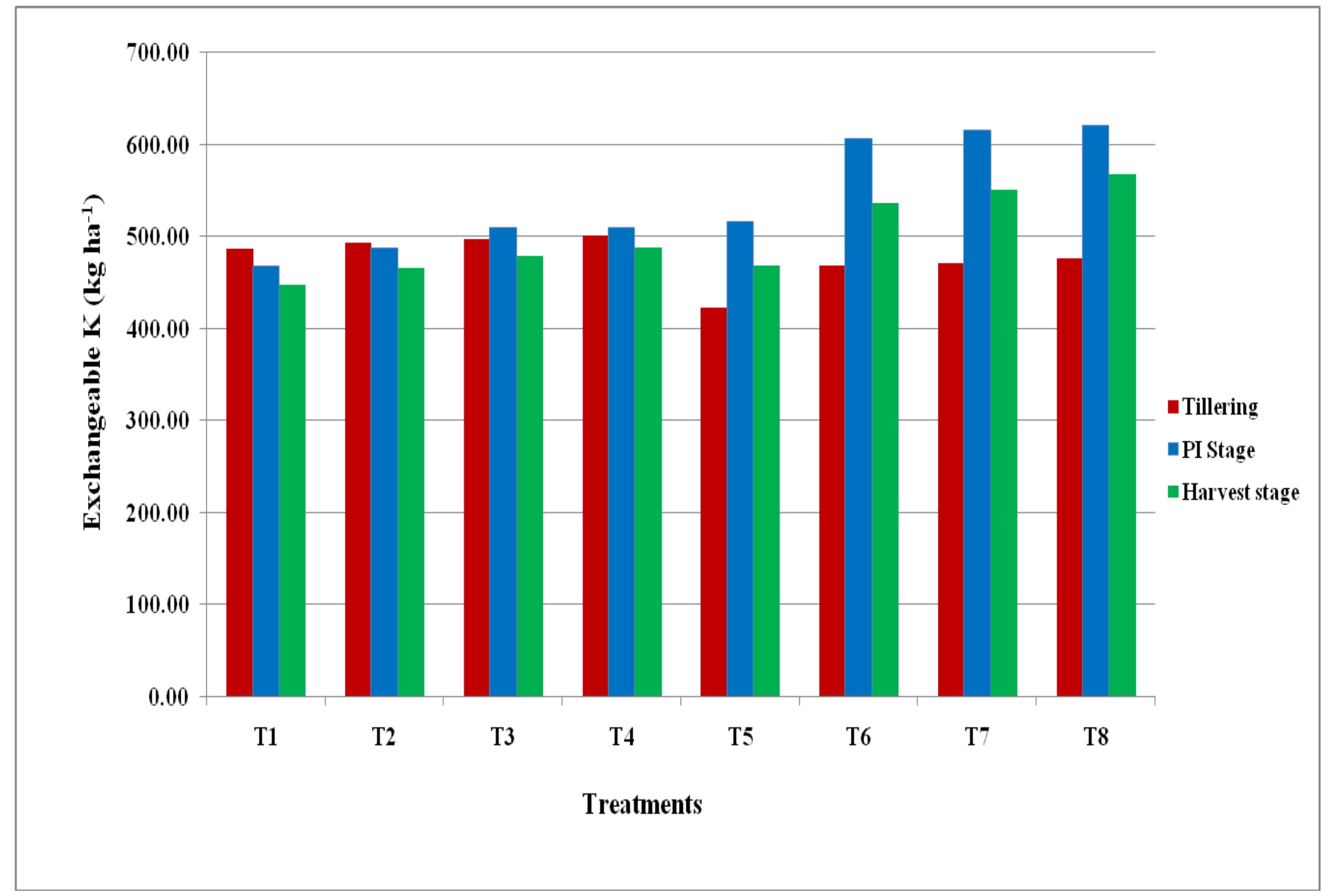


Fig.3 Fixed K as influenced by different levels of potassium and green manure at different stages of crop growth

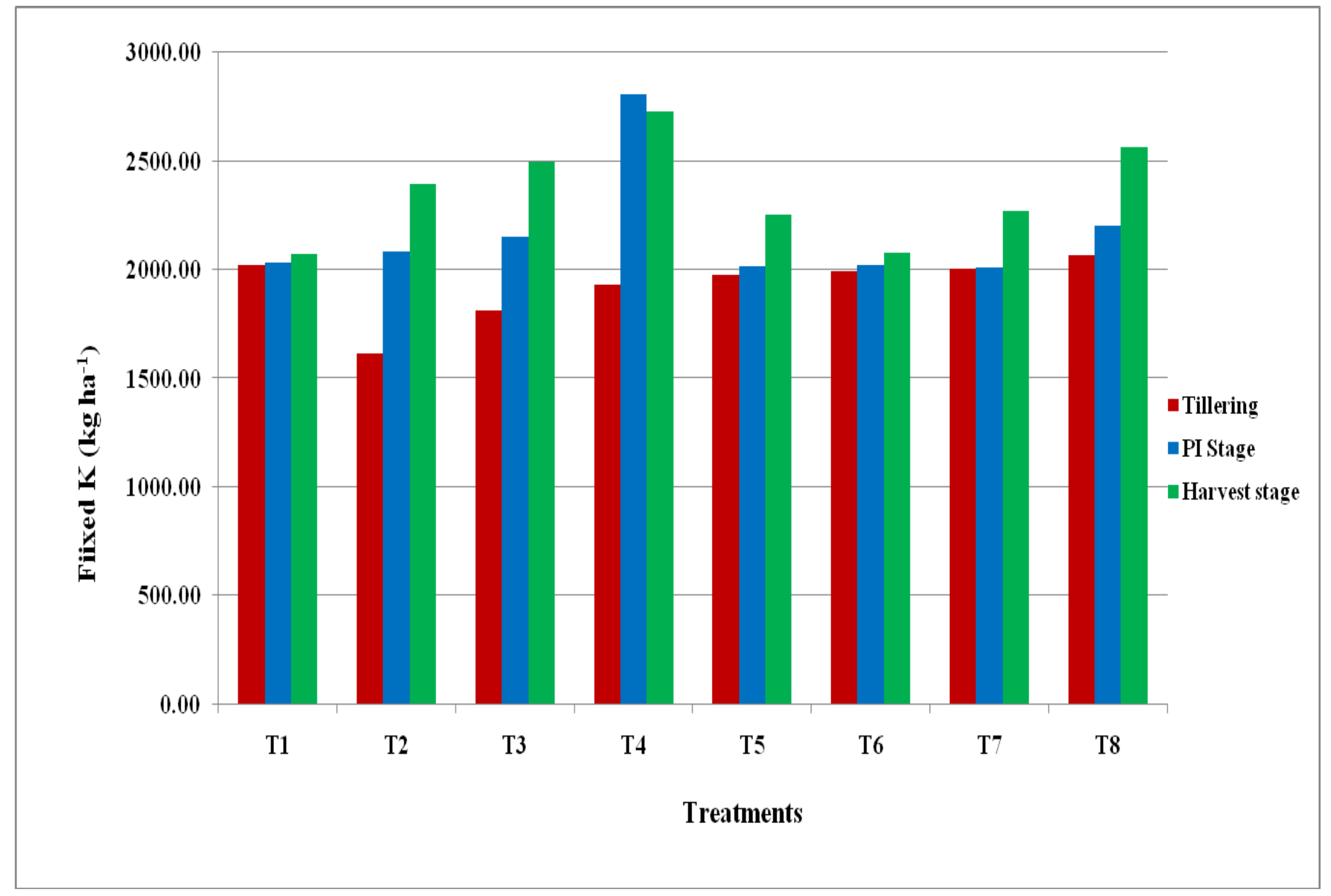


Fig.4 Non exchangeable K as influenced by different levels of potassium and green manure at different stages of crop growth

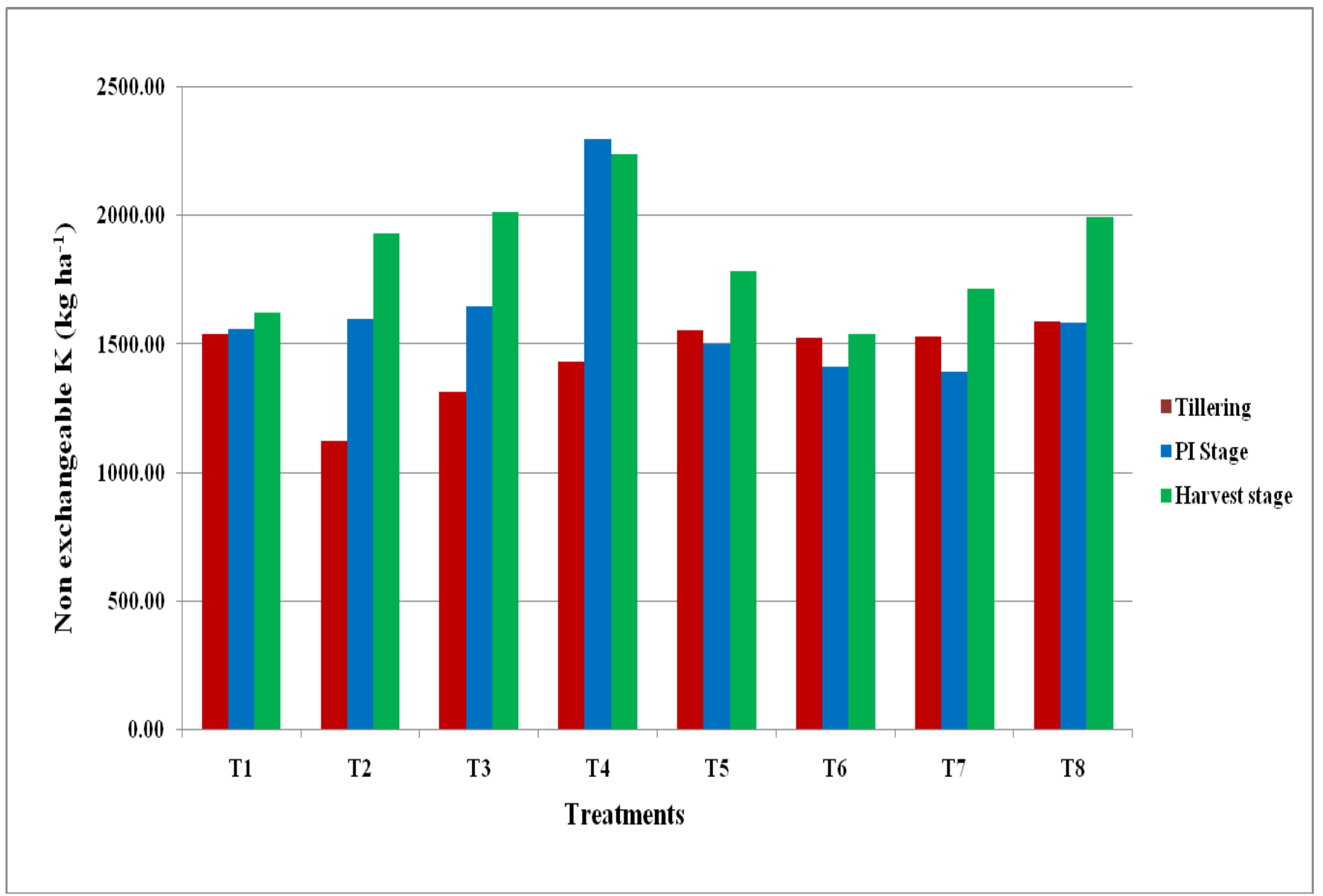


Table.1 Different forms of $\mathrm{K}$ as influenced by green manure and $\mathrm{K}$ at different stages of crop growth in Rice

\begin{tabular}{|c|c|c|c|c|c|c|c|c|c|c|c|c|}
\hline & \multicolumn{3}{|c|}{ Water soluble $\mathrm{K}$} & \multicolumn{3}{|c|}{ Exchangeable $\mathrm{K}$} & \multicolumn{3}{|c|}{ Fixed K } & \multicolumn{3}{|c|}{ Non exchangeable $\mathrm{K}$} \\
\hline Treatments & Tillering & $\mathrm{PI}$ & Harvest & Tillering & $\mathrm{PI}$ & Harvest & Tillering & $\mathrm{PI}$ & Harvest & Tillering & $\mathrm{PI}$ & Harvest \\
\hline $\mathrm{T}_{1}: 0 \%$ RDK (Control) & 80 & 102 & 114 & 487 & 469 & 448 & 2025 & 2031 & 2073 & 1458 & 1454 & 1512 \\
\hline $\mathrm{T}_{2}: 50 \%$ RDK $\left(40 \mathrm{~kg} \mathrm{~K}_{2} \mathrm{O} \mathrm{ha}^{-1}\right)$ & 88 & 113 & 125 & 494 & 487 & 466 & 1615 & 2085 & 2396 & 1033 & 1492 & 1805 \\
\hline $\mathrm{T}_{3}: 100 \% \mathrm{RDK}\left(80 \mathrm{~kg} \mathrm{~K}_{2} \mathrm{O} \mathrm{ha}^{-1}\right)$ & 98 & 119 & 134 & 498 & 508 & 480 & 1813 & 2155 & 2494 & 1217 & 1528 & 1880 \\
\hline $\mathrm{T}_{4}: 150 \% \mathrm{RDK}\left(120 \mathrm{~kg} \mathrm{~K}_{2} \mathrm{O} \mathrm{ha}^{-1}\right)$ & 118 & 134 & 146 & 501 & 509 & 489 & 1933 & 2806 & 2730 & 1314 & 2167 & 2095 \\
\hline $\mathrm{T}_{5}$ : GM (dhaincha)in situ only & 136 & 103 & 133 & 423 & 515 & 469 & 1977 & 2015 & 2253 & 1418 & 1393 & 1651 \\
\hline $\mathrm{T}_{6}: \mathrm{GM}+40 \mathrm{~kg} \mathrm{~K}_{2} \mathrm{O} \mathrm{ha}{ }^{-1}$ & 145 & 111 & 130 & 468 & 606 & 537 & 1993 & 2020 & 2077 & 1380 & 1299 & 1410 \\
\hline $\mathrm{T}_{7}: \mathrm{GM}+80 \mathrm{~kg} \mathrm{~K}_{2} \mathrm{O} \mathrm{ha}^{-1}$ & 155 & 122 & 138 & 471 & 615 & 551 & 2003 & 2011 & 2270 & 1377 & 1273 & 1582 \\
\hline $\mathrm{T}_{8}: \mathrm{GM}+120 \mathrm{~kg} \mathrm{~K}_{2} \mathrm{O} \mathrm{ha}^{-1}$ & 165 & 141 & 145 & 477 & 621 & 568 & 2065 & 2205 & 2567 & 1423 & 1462 & 1853 \\
\hline $\mathrm{SE}(\mathrm{m}) \pm$ & 4.8 & 6.4 & 4.2 & 11 & 7 & 13 & 41 & 14.2 & 7.09 & 46.3 & 66 & 13 \\
\hline $\mathrm{CD}(\mathrm{P}=0.05)$ & 15 & 20 & 13 & 34 & 20 & 40 & 124 & 43.6 & 21.7 & 141 & 204 & 39 \\
\hline $\mathrm{CV}$ & 6 & 9 & 5 & 4 & 2 & 5 & 3 & 2 & 1 & 6 & 8 & 1 \\
\hline
\end{tabular}

Table.3 Yield attributes as influenced by different levels of potassium and green manure

\begin{tabular}{|c|c|c|c|c|c|}
\hline Treatments & $\begin{array}{c}\text { Number of } \\
\text { tillers } / \mathbf{m}^{2}\end{array}$ & $\begin{array}{c}\text { No. of productive } \\
\text { Tillers } / \mathbf{m}^{2}\end{array}$ & $\begin{array}{c}\text { Number of } \\
\text { grains/panicle }\end{array}$ & $\begin{array}{c}\text { Filled grains/ } \\
\text { panicle }\end{array}$ & $\begin{array}{c}\text { Test weight } \\
\text { (g) }\end{array}$ \\
\hline $\mathrm{T}_{1}: 0 \%$ RDK (Control) & 455 & 411 & 133 & 124 & 14.03 \\
\hline $\mathrm{T}_{2}: 50 \% \mathrm{RDK}\left(40 \mathrm{~kg} \mathrm{~K}_{2} \mathrm{O} \mathrm{ha}^{-1}\right)$ & 477 & 444 & 153 & 142 & 14.53 \\
\hline $\mathrm{T}_{3}: 100 \% \mathrm{RDK}\left(80 \mathrm{~kg} \mathrm{~K}_{2} \mathrm{O} \mathrm{ha}^{-1}\right)$ & 500 & 455 & 154 & 141 & 14.73 \\
\hline $\mathrm{T}_{4}: 150 \% \mathrm{RDK}\left(120 \mathrm{~kg} \mathrm{~K}_{2} \mathrm{O} \mathrm{ha}^{-1}\right)$ & 522 & 500 & 155 & 145 & 15.04 \\
\hline $\mathrm{T}_{5}: \mathrm{GM}$ (dhaincha)in situ only & 555 & 489 & 152 & 144 & 14.89 \\
\hline $\mathrm{T}_{6}: \mathrm{GM}+40 \mathrm{~kg} \mathrm{~K}_{2} \mathrm{O} \mathrm{ha}^{-1}$ & 577 & 533 & 153 & 146 & 15.67 \\
\hline $\mathrm{T}_{7}: \mathrm{GM}+80 \mathrm{~kg} \mathrm{~K}_{2} \mathrm{O} \mathrm{ha}^{-1}$ & 622 & 544 & 156 & 147 & 15.74 \\
\hline $\mathrm{T}_{8}: \mathrm{GM}+120 \mathrm{~kg} \mathrm{~K}_{2} \mathrm{O} \mathrm{ha}{ }^{-1}$ & 733 & 677 & 158 & 149 & 15.86 \\
\hline $\mathrm{SE}(\mathrm{m}) \pm$ & 9.85 & 13.03 & 1.4 & 1.8 & 0.17 \\
\hline $\mathrm{CD}(\mathrm{p}=0.05)$ & 31 & 40 & 4.13 & 5.51 & 0.53 \\
\hline $\mathrm{CV} \%$ & 3.07 & 4.45 & 1.54 & 2.20 & 1.99 \\
\hline
\end{tabular}


Table 2. Grain and straw yield a influenced by different levels of potassium and green manure

\begin{tabular}{|l|c|c|}
\hline \multicolumn{1}{|c|}{ Treatments } & \multicolumn{1}{|c|}{$\begin{array}{c}\text { Grain yield } \\
\left(\mathbf{k g ~ h a}^{-1}\right)\end{array}$} & $\begin{array}{c}\text { Straw yield } \\
\left(\mathbf{k g ~ h a}^{-1}\right)\end{array}$ \\
\hline $\mathrm{T}_{1} \cdot 0 \% \mathrm{RDK}($ Control $)$ & 5008 & 6173 \\
\hline $\mathrm{T}_{2} \cdot 50 \% \mathrm{RDK}\left(40 \mathrm{~kg} \mathrm{~K}_{2} \mathrm{O} \mathrm{ha}^{-1}\right)$ & 5281 & 6716 \\
\hline $\mathrm{T}_{3} \cdot 100 \% \mathrm{RDK}\left(80 \mathrm{~kg} \mathrm{~K}_{2} \mathrm{O} \mathrm{ha}^{-1}\right)$ & 5433 & 7664 \\
\hline $\mathrm{T}_{4} \cdot 150 \% \mathrm{RDK}\left(120 \mathrm{~kg} \mathrm{~K}_{2} \mathrm{O} \mathrm{ha}^{-1}\right)$ & 5517 & 7830 \\
\hline $\mathrm{T}_{5} \cdot \mathrm{GM}($ dhaincha)in situ only & 5493 & 8979 \\
\hline $\mathrm{T}_{6} \cdot \mathrm{GM}+40 \mathrm{~kg} \mathrm{~K}_{2} \mathrm{O} \mathrm{ha}^{-1}$ & 5552 & 9617 \\
\hline $\mathrm{T}_{7} \cdot \mathrm{GM}+80 \mathrm{~kg} \mathrm{~K}_{2} \mathrm{O} \mathrm{ha}^{-1}$ & 5671 & 10403 \\
\hline $\mathrm{T}_{8} \cdot \mathrm{GM}+120 \mathrm{~kg} \mathrm{~K}_{2} \mathrm{O} \mathrm{ha}^{-1}$ & 5748 & 10931 \\
\hline $\mathrm{SE}(\mathrm{m}) \pm$ & 95 & 465 \\
\hline $\mathrm{CD}(\mathrm{P}=0.05)$ & 292 & 1424 \\
\hline $\mathrm{CV}$ & 5 & 7 \\
\hline
\end{tabular}

\section{Non-exchangeable K}

Similar to fixed $\mathrm{K}$, the non-exchangeable $\mathrm{K}$ increased from tillering to harvest stage (Table 1 and Fig. 4). At tillering stage the highest non-exchangeable $\mathrm{K}$ was observed in control, except $\mathrm{T}_{8}\left(\mathrm{G} \cdot \mathrm{M}+120 \mathrm{~kg} \mathrm{~K}_{2} \mathrm{O} \mathrm{ha}{ }^{-1}\right)$. In later stages i.e., panicle initiation and harvest stages, the highest non- exchangeable $\mathrm{K}$ was observed at $\mathrm{T}_{4}\left(120 \mathrm{~kg} \mathrm{~K}_{2} \mathrm{O} \mathrm{ha}^{-1}\right)$. The results further showed that increasing the level of fertilizer from 0 to $120 \mathrm{~kg} \mathrm{ha}^{-1}$ increased the non- exchangeable form of $\mathrm{K}$ at all stages of crop growth. This indicates that fixation of $\mathrm{K}$ increased with addition of K (Sarada, 1988; Talely et al., 1993).
Application of green manure showed higher values of non-exchangeable form of $\mathrm{K}$ when compared with all $\mathrm{K}$ fertilizer treatments at tillering stage. This might be due to prevent the leaching of water soluble form and conversion water soluble $\mathrm{K}$ to nonexchangeable $\mathrm{K}$.

\section{Yield}

All the treatments recorded significantly higher grain and straw yield than control except $\mathrm{T}_{2}\left(40 \mathrm{~kg} \mathrm{~K}_{2} \mathrm{O} \mathrm{ha}^{-1}\right)$ (Table 2). Grain and straw yield increased with increasing levels of $\mathrm{K}$ up to120 $\mathrm{kg} \mathrm{K}_{2} \mathrm{O} \mathrm{ha}^{-1}$. However, there was no statistical difference between the 
three levels of $\mathrm{K}\left(40,80\right.$ and $\left.120 \mathrm{~kg} \mathrm{~K}_{2} \mathrm{O} \mathrm{ha}^{-1}\right)$ in increasing grain and straw yield. The increased grain and straw yield by the application of $\mathrm{K}$ fertilizer was due to the continuous supply of $\mathrm{K}$ to the during crop growth period which was more beneficial and increased total no of tillers, No of productive tillers, number of grains per panicle and test weight (Table 3) resulted higher yields of rice (Meena et al., 2003; Surekha et al., 2003).

Application of green manure in combination with $\mathrm{K}$ recorded higher grain and straw yield than when applied alone. The highest grain and straw yield were obtained with $\mathrm{T}_{8}(\mathrm{GM}+$ $120 \mathrm{~kg} \mathrm{~K}_{2} \mathrm{O} \mathrm{ha}^{-1}$ ), but which were on par with $\mathrm{T}_{7}\left(\mathrm{GM}+80 \mathrm{~kg} \mathrm{~K}_{2} \mathrm{O} \mathrm{ha}{ }^{-1}\right)$ and $\mathrm{T}_{6}(\mathrm{GM}+40$ $\mathrm{kg} \mathrm{K}_{2} \mathrm{O}$ ha $^{-1}$ ). Green manure in combinations with $\mathrm{K}$ fertilizers increased the grain yield due to increased total no of tillers, No of productive tillers, number of grains per panicle and test weight (Table 3) and decomposition of succulent green manure crop, which favoured for release of nutrients and their continuous availability in soil for sustaining higher grain and straw yield of rice. Highest grain yield with green manure along with NPK fertilizers in rice was also reported by Sharma et al., (2001) and Singh et al., (2002).

The results showed that increasing the level of $\mathrm{K}$ fertilizer from 0 to $120 \mathrm{~kg} \mathrm{~K} \mathrm{O}_{2} \mathrm{ha}^{-1}$ increased the yield and all forms of $\mathrm{K}$ at all stages of crop growth. Green manure in combination with potassium fertilizer recorded the higher yield as well as water soluble and exchangeable form of $\mathrm{K}$. But increasing the level of fertilizer from 0 to 120 $\mathrm{kg} \mathrm{ha}^{-1}$ increased the non- exchangeable and fixed form of $\mathrm{K}$ at all stages of crop growth. The highest fixed $\mathrm{K}$ and non-exchangeable $\mathrm{K}$ was observed at $120 \mathrm{~kg} \mathrm{~K}_{2} \mathrm{O} \mathrm{ha}^{-1}\left(\mathrm{~T}_{4}\right)$ whereas the highest yield, water soluble and exchangeable form were obtained with form $\left(\mathrm{T}_{8}\right) \mathrm{GM}+120 \mathrm{~kg} \mathrm{~K}_{2} \mathrm{O} \mathrm{ha}^{-1}$ which was on par with $\left(\mathrm{T}_{7}\right) \mathrm{GM}+80 \quad \mathrm{~kg} \quad \mathrm{~K}_{2} \mathrm{O} \quad \mathrm{ha}^{-1}$ and $\left(\mathrm{T}_{6}\right)$ $\mathrm{GM}+40 \mathrm{~kg} \mathrm{~K}_{2} \mathrm{O} \mathrm{ha}{ }^{-1}$. Hence, the incorporation of green manure (dhaincha) at flowering stage before transplanting along with $40 \mathrm{~kg}$ $\mathrm{K}_{2} \mathrm{O}$ ha $^{-1}$ may be recommended for rice crop. However extensive field trails in farmer's fields is also recommended for further validation of the results.

\section{References}

Dhudhan, B.S., Grewal, K.S Dahiya, S.S. and Singh, N.(2004). Comparative efficiency of different green manure in improving and nutrition of rice. Haryana Agricultural University and Research. 34: 71-74.

Jackson, M.L (1973). Soil Chemical Analysis. Prentice Hall of India Private Limited, New Delhi.

Kanwar, J. S and Grewal, J.S.1966. The relationship between forms of soil potassium and particle size. Journal of the Indian Society of Soil Science. 14: 221-225.

Meena,S., Singh,S and Shivay,Y.S. 2003. Response of hybrid rice (Oryza sativa) to nitrogen and potassium application in sandy clay loam soils. Indian Journal of Agricultural Sciences. 73(1):8-11.

Patra, A.K., Nayaki, B.C.and Mishra, M.M. 2000. Integrated management in Rice (Oryza Sativa)-wheat (Triticum aestivum) cropping system. Indian Journal of Agronomy. 45(3): 453-457.

Rao, Ch. S., Subba Rao, A and Rupa, T.R 2000. Plant mobilization of soil reserve potassium from fifteen smectitic soils in relation to soil test potassium and mineralogy. Soil Science. 165: 578-586.

Sarada, A. 1988. Studies on potassium in Deltaic rice soils of AndhraPradesh. M.Sc.(Ag.)Thesis submitted to Acharya N.G. Ranga Agricultural University, Hyderabad. India.

Shama, M. P., Bali, S. V. and Gupta D. K. 
2001. Soil fertility and productivity of rice - wheat cropping system in an Inceptisol as influenced by integrated nutrient management. Indian Journal of Agricultural Sciences. 71: 82-86.

Singh, G., Singh, O. P., Singh, R.G., Mehta, R.K.,Kumar,V and Singh, R.P. (2006). Effect of integrated nutrient management on yield and nutrient uptake of rice (Oryza sativa) -wheat (Triticum aestivum) cropping systems in low lands of eastern uttara Pradesh. Indian Journal of Agronomy. 51(2): 8588.

Singh, R.P., Singh, P. K., and Singh, A. K. (2009). Effect of green manuring on physico- chemical properties of soil and productivity of rice. Oryza. 48 (2):120123.

Singh,B., Singh,Y., Imas, $\mathrm{P}$ and XieJian Chang. (2004). Potassium nutrition of the rice-wheat cropping system. Advances in Agronomy. 81: 203-259.

Singh., Surendra Singh, R.N., Prasad, J. and Kumar, B. (2002). Effect of green manuring, FYM and biofertilizers in relation to fertilizer nitrogen and major nutrient uptake by upland rice. Journal of the Indian Society of Soil Science. 50(1-4): 313-314.
Surekha, K., Reddy, M. N. and Bala Subramanian, V. (2003). Effect of potassium application on yield and nutrient use efficiency of rice hybrids and conventional varieties. Journal of Potassium Research. 19: 55-60.

Swarup, A. (1991). Long term effect of green manuring (Sesbania aculeata) on soil properties and sustainability of rice and wheat on a sodic soil. Journal of the Indian Society of Soil Science. 39(4): 777-780.

Syers, J. K., Sheldrick, W.F and Lingard, J. (2011). Nutrient depletion in Asia :how serious in the problem? Proceedings of $12^{\text {th }}$ world fertilizer congress of the CIEC, August 2001, Beijing, china.

Talely, P. E., Zende, G. K., Patil, Y. M., Sonar, K. R and Tamboli, B.D. (1993). Effect of added $\mathrm{k}$ and incubation time on transformation of available $\mathrm{K}$ and non-exchangeable $\mathrm{K}$ in different soils of Maharashtra. Journal of Indian Society of Soil Science. 41(2): 238-24.

Wood, L.K and De Turk, E.E. (1941). The absorption of potassium in soils in nonreplaceable forms. Proceedings of Soil Science Society of America. 5: 152-161.

\section{How to cite this article:}

Sujatha, D.V., P. Kavitha and Naidu, M.V.S. 2017. Influence of Green Manure and Potassium Nutrition on Soil Potassium Fractions and Yield of Rice Crop. Int.J.Curr.Microbiol.App.Sci. 6(11): 13-23. doi: https://doi.org/10.20546/ijcmas.2017.611.002 